\title{
MANUFACTURING AND ASSESSMENT OF A UNIT FOR PRODUCING HYDROGEN GAS FROM WATER
}

Fouda, T. Z., (1) Badr, S. E., ${ }^{(2)}$ Drbala, A. A. E., ${ }^{(3)}$

Elmetwalli, A. M. H., ${ }^{(4)}$ and Abou Elmagd, E.A. ${ }^{(5)}$

\section{ABSTRACT}

The main objectives of this research were to design a small unit for the production of hydrogen gas from water, to rationalize the use of energy needed for the separation of hydrogen. Also determine the water quality for hydrogen production, and test the optimal geometry for producing higher levels of hydrogen gas. The experimental results of hydrogen cells production unit are presented. It is used for electrical analysis of three types of water (tap - acidic - saline). The results obtained showed that the highest production of hydrogen energy was observed with 15 cells number was $5.12 \mathrm{kWh}$ at working time $60 \mathrm{~min}$, distance between cells 0.5 $\mathrm{mm}$, cell temperature $46.7^{\circ} \mathrm{C}$ and water temperature $56.1^{\circ} \mathrm{C}$ in the presence of saline water. At same time the lowest hydrogen energy observed with number of cells 15 cells number was $1.788 \mathrm{kWh}$, working time $15 \mathrm{~min}$, distance between cells $1.5 \mathrm{~mm}$, cell temperature was $30.6^{\circ} \mathrm{C}$ and water temperature was $29.9^{\circ} \mathrm{C}$ in the presence of tap water. Total energy was increased by $186.52 \%$, increasing number of cells and lack of distance between cells.

\section{INTRODUCTION}

$\mathrm{H}$ ydrogen gas is pure, high quality fuel, environmentally friendly and can be used to operate engines to achieve various agricultural operations, generate electricity, using simple energy of electricity as a source from water analysis. hydrogen and oxygen can be produced from water using electricity with an electrolyzed. Walt et al. (1994) Stated that the installation and operation of a 12 cell Hydrogen Wind Inc. 1000 Watt electrolyzed. This electrolyzed can produce 170 liters/hour (6 cubic feet/hour) of hydrogen and 85 liters/hour (3 cubic feet/hour) of oxygen (at standard temperature and pressure).

(1)، (3) Prof. of Agric. Eng., fac. of Agric., Tanta University.

(2) Prof. Emt. of Agric. Eng., Agric. Eng. Res. Inst.

(4) Associate Prof. of Agric. Eng., fac. of Agric., Tanta University.

(5) Assitant researcher of Agric. Eng., Agric. Eng. Res. Inst. 
Hailed et al. (2001) declared that the fuel cell generally consists of two electrodes, the anode and the cathode, separated by an electrolyte. Fuel cells high temperature based on molten carbonate (MCFC) or solid oxide (SOFC) technology operate at sufficiently high temperatures to run directly on methane. This is sometimes called "internal reforming." Thus, MCFC and SOFC systems do not need a pure or relatively pure hydrogen stream as do proton exchange membrane (PEM) and phosphoric acid (PAFC) systems, but can run directly on natural gas or biogas or landfill gas. Andre at el. (2001) searched every fuel can liberate a fixed amount of energy when it reacts completely with oxygen to form water. This energy content is measured experimentally and is quantified by a fuel's higher heating value $(\mathrm{HHV}=141.86 \mathrm{MJ} / \mathrm{kg})$ and lower heating value $(\mathrm{LHV}=119.93 \mathrm{MJ} / \mathrm{kg}$ ). The difference between the HHV and the LHV is the "heat of vaporization" and represents the amount of energy required to vaporize a liquid fuel into a gaseous fuel, as well as the energy used to convert water to steam. Trygve et al. (2006) stated the total energy that is needed for water electrolysis is increasing slightly with temperature, while the required electrical energy decreases. A high-temperature electrolysis process might, therefore, be preferable when hightemperature heat is available as waste heat from other processes. Kaveh et al. (2012) The main reason was stated to be the shrinking effect of pressure on the gas bubbles which cause the comic voltage drop and power dissipation to reduce. Moreover, high pressure electrolysis has less power demand for the phase of product compression. They conducted their experiments were conducted in a typical three compartment electrolyte with a varying temperature between $25^{\circ} \mathrm{C}$ and $90^{\circ} \mathrm{C}$. Cell current density was kept at $1 \mathrm{am} \mathrm{cm}^{-2}$ with an electrolyte of either a $34 \%$ wt or $25 \%$ wt $\mathrm{KOH}$ solution in distilled water. Romdhane (2013) According to the type of used electrolyte (tap water, margin, gas, liquor, waste water from cooking, puckered olive, urine, vinegar of pink, municipal waste water and finally milk, water), there is variation of the hydrogen flow rate produced by supplying the electrolytes in electrical current by the photovoltaic module as the energetic efficiency does not change often in the same direction as the produced hydrogen flow. This voltage is not the operating voltage of fuel cell have shown us. Our first 
task is to show why the initial theoretical voltages are different. By applying alone we can see that the EMF of the fuel cell is directly dependent on the desired operational temperature, this is the case because we have seen in the last chapter that volume is directly dependent on temperature. Jyothi1 and Reddy (2014) enabled such systems can be designed to produce additional purified hydrogen as a byproduct (e.g. for use as a vehicle fuel), by feeding additional fuel and then purifying the hydrogen-rich "anode tail gas" from the fuel cell into purified hydrogen. (Ogden 2014) Hydrogen production via electrolysis of water seems to be the most viable method. A small unit to produce hydrogen gas from stainless steel was designed with a number of cells $(9,11,13,15$ cells), cell distance $(1.5,1.0,0.5 \mathrm{~mm})$, duration of unit operation $(15,30,45,60$ min) and Type of water (Tap water, Acidic water and Saline water (sea water in particular)). The water temperature and temperature of the cell were measured to show the extent of their effect and the effect of the study factors on the quantity of produced gas $(1 / h)$ and the quantity of energy produced and consumed (kWh).The main objectives of this work to design a small hydrogen gas production unit to produce hydrogen gas from different water type and evaluation of the process of producing hydrogen gas.

\section{MATERIAL AND METHODS}

This research work was carried out at Gemmeiza Agricultural Research Station, Department of Agricultural Engineering and Agricultural Research Center in Giza, to investigate the possibility of manufacture a small unit to producing hydrogen gas from water.

\section{Study parameters}

Four different study parameters were investigated including water type, space between cells and working time.

* Water type (Tap - Acidic - Saline (sea water in particular)).

* Distance between cells (0.5 - $1.0-1.5 \mathrm{~mm})$.

* Number of cells were used ( 9 - $11-13$ - 15 cells); the highest efficiency was number of cells ( 15 cells).

* Working time (15 - 30 - 45 - 60 - 75 - 90 - 105 - 120 - 135 - 150 min). 


\section{The hydrogen production unit}

The production unit of hydrogen gas consisted of a group stainless sheets of negative and positive poles. Between each two successive stainless steel sheets. Gasket "Aspects" was uses to avoid leakage of both water and hydrogen gas. Gaskets were also used to control the distance between cells. Acrylic covers of $30 \mathrm{~cm} * 35 \mathrm{~cm}$ were used to cover and link the whole unit.

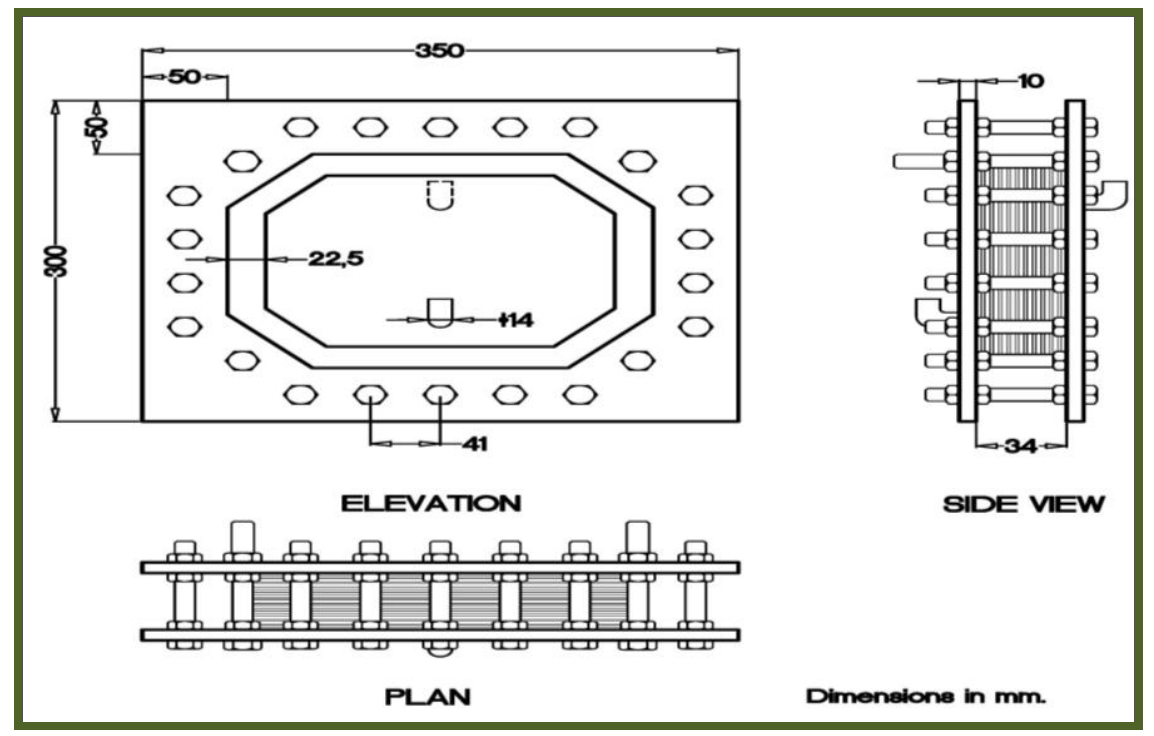

Figure (1): The hydrogen gas production unit, plan, elevation and side view.

Measurement of current intensity and voltage.

MY-61 Digital Multimeter/Volt/Amp/Diode/Ohm/Capacitance tester Transistor VEJ56 T18 0.5 was used for measuring current intensity and voltage.

\section{- Principles of electrolysis}

The principle chemical equations are shown in reaction 1 , where the electrochemical flow is shown for acidic and alkaline environments. This work involves the alkaline reaction pathway.

$$
\text { Net Reaction: } \mathrm{H}_{2} \mathrm{O} \rightarrow \mathrm{H}_{2}+1 / 2 \mathrm{O}_{2}
$$

Acidic Reaction

Anode: $\mathrm{H}_{2} \mathrm{O} \rightarrow 1 / 2 \mathrm{O}_{2}+2 \mathrm{H}^{+}+2 \mathrm{e}^{-}$

Cathode: $2 \mathrm{H}^{+}+2 \mathrm{e}^{-} \rightarrow \mathrm{H}_{2}$
Alkaline Electrolysis

$$
\begin{array}{r}
2 \mathrm{OH}^{-} \rightarrow 1 / 2 \mathrm{O}_{2}+\mathrm{H}_{2} \mathrm{O}+2 \mathrm{e}^{-} \\
2 \mathrm{H}_{2} \mathrm{O}+2 \mathrm{e}^{-} \rightarrow \mathrm{H}_{2}+2 \mathrm{OH}
\end{array}
$$




\section{- Fuel Cell Efficiency}

Fuel cell efficiency is commonly taken to mean the actual efficiency of the electrochemical reaction. This efficiency can be derived as follows.

The amount of energy released when hydrogen and oxygen combine to form water according to the reaction $\mathrm{H}_{2}+1 / 2 \mathrm{O} \rightarrow \mathrm{H}_{2} \mathrm{O}$ is quantified as the "enthalpy of reaction" $\left(\Delta \mathrm{H}^{\circ}\right)$. This value is measured experimentally and depends on whether the water is formed as a gas or a liquid. For fuel cells, the water forms as a gas and the enthalpy of reaction is known to be:

$$
\Delta H^{o}=-230 \frac{\text { BTU }_{\text {water }}}{\text { mole }_{\text {water }}}
$$

mole $_{\text {water }}=6.023 * 10^{23}$ molecules of water

This value of the enthalpy of reaction is only strictly correct at $25^{\circ} \mathrm{C}$ and 1 atmosphere.

Gibbs free energy" $\left(\Delta \mathrm{G}^{\circ}\right)$ for gaseous water at $25^{\circ} \mathrm{C}$ and 1 atmosphere this is known to be: The negative sign denotes that the energy is released during the reaction, and not absorbed. Gibbs free energy can be determined from the following equation.

$$
\Delta G_{\text {gas }}=-217 \frac{B T U}{\text { mole }_{\text {water }}}=-229 \frac{K J}{\text { mole }_{\text {water }}}
$$

The voltage of each cell $\left(\varepsilon_{\text {cell }}\right)$ is related to the Gibbs free energy according to the equation:

$$
\varepsilon_{\text {cell }}=-\frac{\Delta G^{o}}{n \mathcal{F}}
$$

Where:

$\mathrm{n}=$ Number of electrons involved in the reaction. This is most

conveniently Expressed as "mole of electrons" (or mole $\mathrm{e}^{-}$) where each mole $\mathrm{e}^{-}$is equal to $6.023 \times 10^{23}$ electrons. From the anode and cathode reactions $\left(\mathrm{H}_{2} \rightarrow 2 \mathrm{H}^{+} 2 \mathrm{e}^{-}\right.$and $\left.1 / 2 \mathrm{O}_{2}+2 \mathrm{e}^{-}+2 \mathrm{H}^{+} \rightarrow \mathrm{H}_{2} \mathrm{O}\right)$ two electrons are involved in the formation of each water molecule. Thus $\mathrm{n}=2$ mole $\mathrm{e}^{-}$for every 1 mole $_{\text {water }}$ formed.

$\mathcal{F}=$ Faraday's constant. Equal to 96.500 coulombs/mole e $\mathrm{e}^{-}$Coulombs are Aunt of electric charge.

Substituting values into the equation (using imperial units):

$\varepsilon_{\text {cell }}=-\frac{-217 \text { BTU }}{\text { mole }_{\text {water }}} x \frac{1055.7 \mathrm{~J}}{B T U} x \frac{\text { mole }_{\text {water }}}{2 \text { mole e }^{-}} x \frac{\text { mole } e^{-}}{96.500 \text { coul }}=\frac{1.187 \mathrm{~J}}{\text { coul }}=1.187 \mathrm{~V}$

Similarly, using metric units: 
$\varepsilon_{\text {cell }}=-\frac{-229 \mathrm{BTU}}{\text { mole }_{\text {water }}} x \frac{1000 \mathrm{~J}}{\mathrm{KJ}} x \frac{\text { mole }_{\text {water }}}{2 \text { mole e }^{-}} x \frac{\text { mole } \mathrm{e}^{-}}{96.500 \text { coul }}=\frac{1.187 \mathrm{~J}}{\text { coul }}=1.187 \mathrm{~V}$

Thus each cell can generate a maximum theoretical voltage of $1.187 \mathrm{~V}$ (at $25^{\circ} \mathrm{C}$ and 1 atmosphere). The fuel cell efficiency is therefore simply the proportion of the actual voltage the cell produces with respect to this theoretical maximum:

Efficiency cell $=\frac{V_{\text {Acuall }}}{\varepsilon_{\text {cell }}} \cong \frac{V_{\text {Acuall }}}{1.2 \mathrm{~V}}$

For a real fuel cell, typical voltages are between 0.5 and $0.6 \mathrm{~V}$ at normal operating loads and can reach $1.1 \mathrm{~V}$ at open circuit conditions.

\section{3- Efficiency of the unit for producing hydrogen gas}

It was calculated according Mario et al. (2007) Equation:-

$$
\left(p+\frac{n^{2} a}{V^{2}}\right)(V-n b)=n R T
$$

Where: $\mathbf{V}=$ Size $\left(\mathrm{m}^{3}\right)$

$$
\begin{aligned}
& \mathbf{n}=\text { Number of moles. } \\
& \mathbf{T}=\text { Temperature }\left({ }^{\circ} \mathrm{C}\right) \mathbf{p}=\text { Pressure }\left(\mathrm{P}_{\mathrm{a}}\right) \mathbf{R}=\text { Constant. } \\
& \mathbf{a}=\text { Coefficient approximation to the impact of reform pressure } \\
& \mathbf{b}=\text { Coefficient approximation to reform the effect size. }
\end{aligned}
$$

\section{RESULTS AND DISCUSSIONS}

The unit production of hydrogen gas test, data has been collected to get the best set of operating standards under study analysis. The results of this current work discussed under the following headings:

\section{1- Effect of distance between cells and working time on produced energy.}

The results showed in Figure (2) that the production of energy after continuous working time $15 \mathrm{~min}$, distance between cells $1.5 \mathrm{~mm}$ at number of cells 15 cells with saline water was highest than tap water by $110.46 \%$, and with acidic water by $44.40 \%$. While the production of energy after continuous working time $60 \mathrm{~min}$, distance between cells 0.5 $\mathrm{mm}$ at number of cells 15 cells with saline water was highest than tap water by $79.50 \%$ and with acidic water by $44.84 \%$. This is evident from hydrogen gas production unit using tap water and working time (15 to 60 min). The lowest energy of hydrogen gas was (1.788, 2.055, 2.396, 2.454 $\mathrm{kWh}$ ) with distance between cells $1.5 \mathrm{~mm}$ at number of 15 cells. While the highest hydrogen gas capacity was $(2.185,2.409,2.688,2.854 \mathrm{kWh})$ 
continuous working time (15 to $60 \mathrm{~min}$ ) with distance between cells 0.5 $\mathrm{mm}$ at number of 15 cells. While the hydrogen gas production unit using acidic water had the lowest

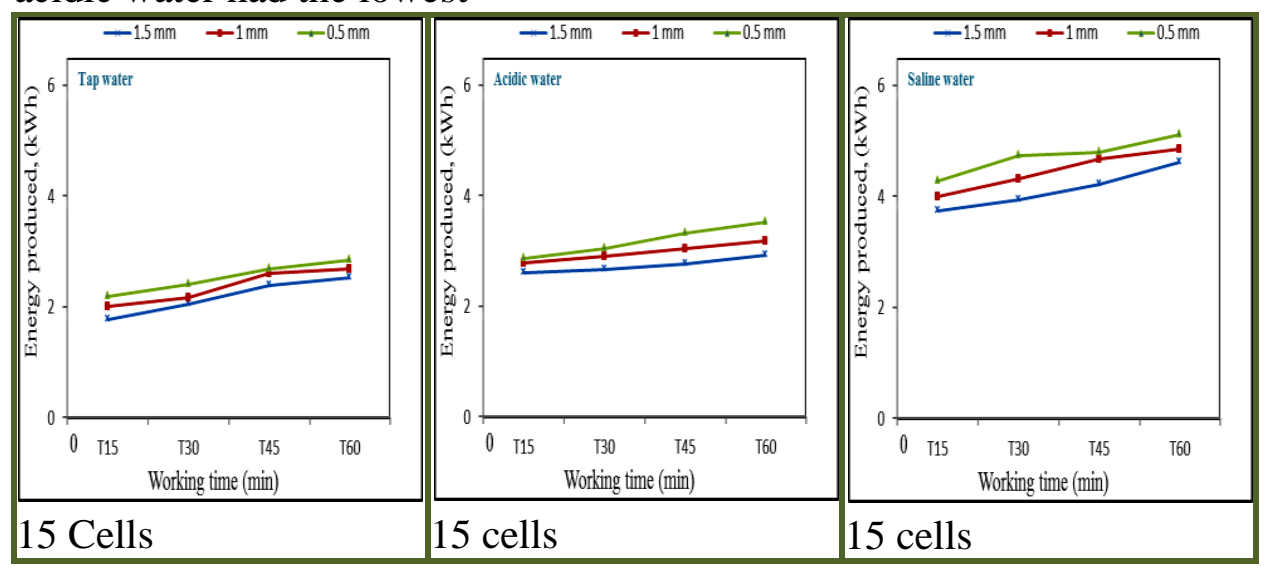

Figure (2): Effect of working time and distance between cells on produced energy $(\mathrm{kWh})$ with three types of water.

energy capacity of $(2.606,2.667,2.767,2.491 \mathrm{kWh})$ continuous working time (15 to $60 \mathrm{~min}$ ), with distance between cells $1.5 \mathrm{~mm}$ at number of cells 15 cells. While the highest hydrogen energy was $(2.881,3.058$, $3.332,3.537 \mathrm{kWh}$ ) continuous working time (15 to $60 \mathrm{~min}$ ) with distance between cells $0.5 \mathrm{~mm}$ at number of 15 cells. While the unit of production of hydrogen gas using saline water was the lowest energy for hydrogen gas $(3.763,3.951,4.217,4.624 \mathrm{kWh})$ continuous working time (15 to 60 min) with distance between cells $1.5 \mathrm{~mm}$ at number of 15 cells. While the highest energy for hydrogen gas $(4.286,4.758,4.791,5.123 \mathrm{kWh})$ continuous working time (15 to $60 \mathrm{~min}$ ) with distance between cells 0.5 $\mathrm{mm}$ at number of 15 cells. This is due to the presence of the negative anion $\left(\mathrm{OH}^{-}\right)$and the positive cations group $\left(\mathrm{C}^{+}\right)$found in saline water, which increases the reaction speed in acidic water and tap water.

\section{2- The relationship between working time and distance between cells} and their effect on water and cell temperature.

The results shown in Figure (3) the comparison between effect of distance between cells and working time on cells temperature and water temperature and its effect on produced energy. It was found that in hydrogen gas production unit of tap water, the lowest of distance between cells from (1.5 to $0.5 \mathrm{~mm}$ ) with number of 15 cells at increase in working 
time from (15 to $60 \mathrm{~min}$ ), water temperature increased from (29.9 to 36.6 $\left.{ }^{\circ} \mathrm{C}\right)$, cells temperature increased from $\left(30.6\right.$ to $\left.45.5^{\circ} \mathrm{C}\right)$,

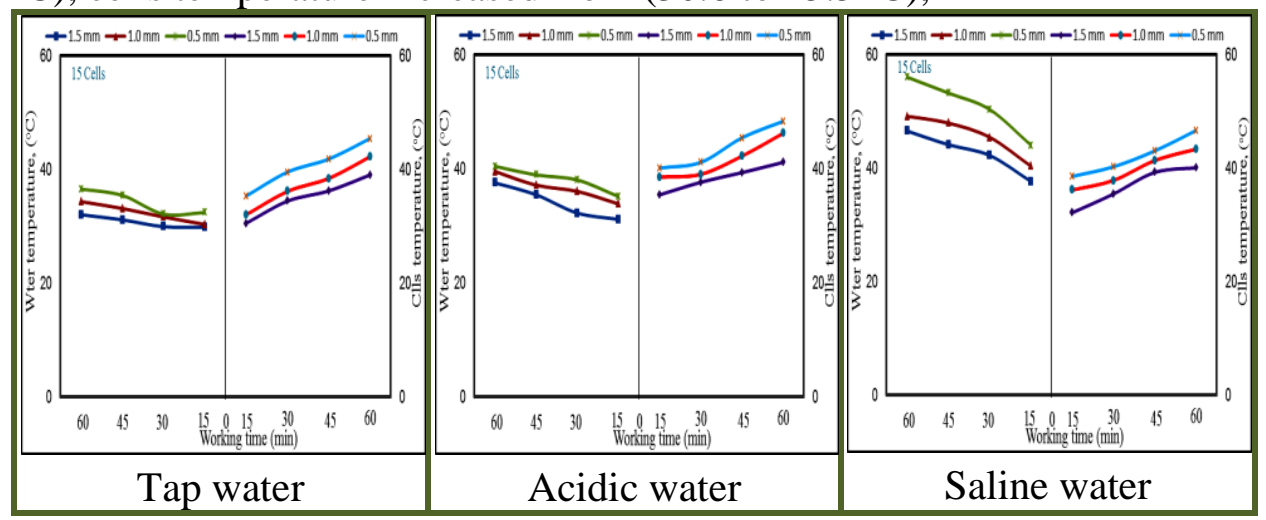

Figure (3): Effect of working time and distance between cells on water and cell temperature

increasing the total produced energy of hydrogen gas from (1.788 to $2.854 \mathrm{kWh}$ ). While using acidic water, the lowest distance between cells (1.5 to $0.5 \mathrm{~mm}$ ), number of 15 cells at increase in working time (15 to 60 min), water temperature increased from $\left(31.2\right.$ to $\left.40.5^{\circ} \mathrm{C}\right)$, cells temperature increased from $\left(35.5\right.$ to $\left.48.4^{\circ} \mathrm{C}\right)$, increasing the total produced energy of hydrogen gas from (2.606 to $3.537 \mathrm{kWh}$ ). By using saline water, with a lowest distance between cells $(1.5$ to $0.5 \mathrm{~mm})$ with number of 15 cells and an increase in working time (15 to $60 \mathrm{~min}$ ), water temperature increased from $\left(37.7\right.$ to $\left.56.1^{\circ} \mathrm{C}\right)$ and cells temperature from (32.2 to $46.7^{\circ} \mathrm{C}$ ) Increases the total produced energy of hydrogen gas from ( 3.763 to $5.123 \mathrm{kWh}$ ). From the above it is clear that, cells temperature of acidic water was greater than cells temperature of saline water, while acidic water temperature was lowest than saline water temperature. This is due to the fact that acidic reaction is quick and chilly, so the cell absorbs more temperature than in the case of saline water. While saline water is neutral (strong alkaline and strong acidic), water absorption is highest than acidic temperature.

\section{3- Influence of water type consumed and produced hydrogen.}

Indicated in Figure (4) the impact of water used in the different types of study in consumed energy and produced energy.

Produced Energy, for the three studid types of water were the averages of results achieved for produced energy when the average distance 
between cells $(0.5,1.0,1.5 \mathrm{~mm})$, number of cells $(9,11,13,15$ cells $)$ and working time $(15,30,45,60 \mathrm{~min})$ as the following:

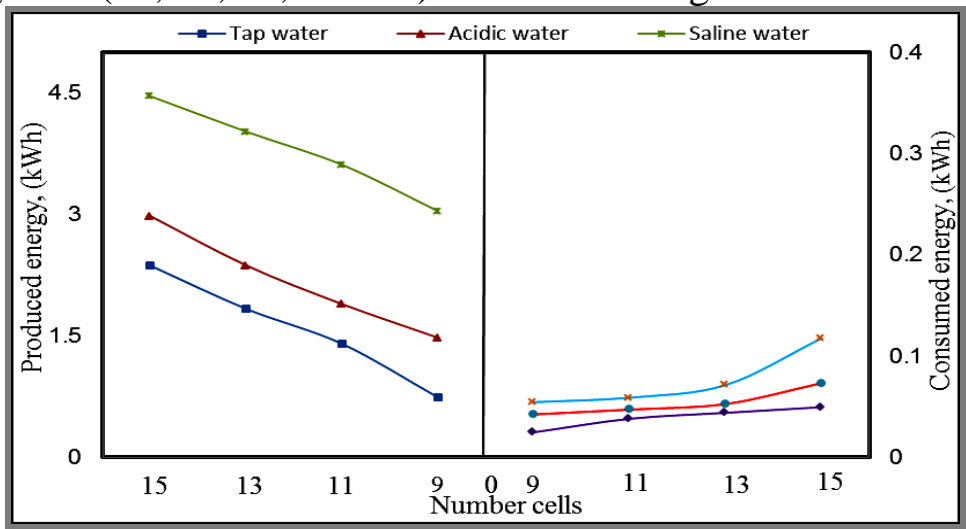

Figure (4): Effect of water types, working time, number of cells and distance cells on produced and consumed energy ( $\mathrm{kWh})$.

Tap water, the average minimum value signed for produced energy $0.741 \mathrm{kWh}$ was obtained when the average distance between cells 1.5 $\mathrm{mm}$, number of 9 cells and working time $60 \mathrm{~min}$. Whereas, the highest value for produced energy $2.367 \mathrm{kWh}$ was obtained at number of 15 cells, working time $60 \mathrm{~min}$ and the average distance between cells $1.5 \mathrm{~mm}$. Acidic water, the average minimum value signed for produced energy $1.478 \mathrm{kWh}$ was obtained when the average distance between cells 1.5 $\mathrm{mm}$, number of 9 cells and working time $60 \mathrm{~min}$. Whereas, the highest value of produced energy $2.979 \mathrm{kWh}$ was obtained at number of 15 cells, working time $60 \mathrm{~min}$ and the average distance between cells $1.5 \mathrm{~mm}$. Saline water, the average minimum value signed for produced energy $3.040 \mathrm{kWh}$ was obtained when the average distance between cells $1.5 \mathrm{~mm}$, number of 9 cells and working time $60 \mathrm{~min}$. Whereas, the highest value of produced energy $4.458 \mathrm{kWh}$ was obtained at number of 15 cells, working time $60 \mathrm{~min}$ and the average distance between cells $1.5 \mathrm{~mm}$. Thus, it is clear from the previous measurements of the difference between the average consumed energy (input) and produced energy (output) that the minimum difference was energy $2.342 \mathrm{kWh}$ for tap water, $2.936 \mathrm{kWh}$ for acidic water and $4.403 \mathrm{kWh}$ for the saline water. Therefore, The best operating and produced energy was obtained from due to the highest value of differences between the consumed and produced energy. 


\section{4- Efficiency of hydrogen gas production unit and effect of distance between cells, working time $\left(\eta^{0}\right)$}

Figure (5) During test period, working time (15 to $120 \mathrm{~min}$ ), distance between cells $(1.5$ to $0.5 \mathrm{~mm}$ ) and three types of water (tap - acidic saline) was the efficiency of cells as follows; In presence of tap water lowest efficiency (25.12\%), working time $150 \mathrm{~min}$ and distance between cells $1.5 \mathrm{~mm}$. The highest efficiency of cells (54.76\%), working time 105 min and distance between cells $0.5 \mathrm{~mm}$.

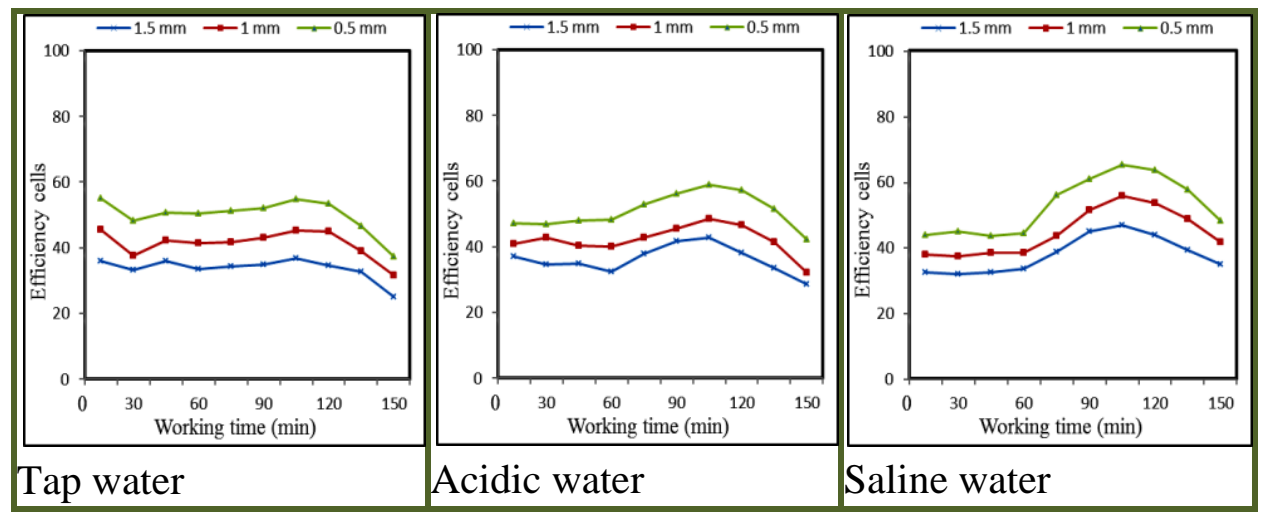

Figure (5): Effect of water types, working time and distance between cells on efficiency cells.

In the presence of lowest efficiency acidic water (28.72\%), working time $150 \mathrm{~min}$ and distance between cells $1.5 \mathrm{~mm}$. The highest efficiency of cells (58.96\%), workin time $105 \mathrm{~min}$ and distance between cells $0.5 \mathrm{~mm}$. In the presence of lowest efficiency saline water (31.91\%), working time $30 \mathrm{~min}$ and distance between cells $1.5 \mathrm{~mm}$. The highest efficiency of cells (65.37\%), working time $105 \mathrm{~min}$ and distance between cells $0.5 \mathrm{~mm}$. In presence of lowest efficiency tap water (25.12\%), working time $150 \mathrm{~min}$ at distance between cells $1.5 \mathrm{~mm}$. The highest efficiency of cells (65.37\%), working time $105 \mathrm{~min}$ and distance between cells $0.5 \mathrm{~mm}$ at saline water. This is because presence of an electrochemical reaction breaks down bonds of its reactors to produced new bonds in resulting materials and to synthesize new materials that are different in their chemical and physical properties. Which results in their deposition on surface of cells, reducing their efficiency by increasing working time. 


\section{CONCLUSIONS}

The highest produced of hydrogen gas was observed with number of cells 15 cells in the presence of saline water, distance between cells $0.5 \mathrm{~mm}$, working time $60 \mathrm{~min}$, cell temperature $46.7^{\circ} \mathrm{C}$ water temperature increased to $56.1^{\circ} \mathrm{C}$ by $5.123 \mathrm{kWh}$. While the lowest produced of hydrogen gas energy was with number of cells 15 cells in used of tap water, distance between cells was $1.5 \mathrm{~mm}$, working time $15 \mathrm{~min}$ ), cell temperature was $30.6^{\circ} \mathrm{C}$ water temperature increased to $29.9^{\circ} \mathrm{C}$ by 1.788 $\mathrm{kWh}$. Thus the increase with saline water was by (186.52\%) the energy produced in the presence of tap water. In the presence of lowest efficiency tap water (25.12\%), working time $150 \mathrm{~min}$ and distance between cells 1.5 $\mathrm{mm}$. The highest efficiency of cells $(65.37 \%)$, working time $105 \mathrm{~min}$ and distance between cells $0.5 \mathrm{~mm}$ at saline water.

\section{REFERENCES}

Andre, L.; J. Heffel and C. Messer (2001). "Hydrogen Fuel Cell Engines and Related Technologies." College of the Desert, Palm Desert, U.S.A Energy Technology Training Center 43-500 Monterey Avenue Palm Desert, CA: 92260 Hydrogen properties " Revision 0, Pp: 1 - 47.

Haile Sossina M. , Dane A. Boysen, Calum R. I. Chisholm, Ryan B. Merle (2001). "Solid Acids as Fuel Cell Electrolytes." Materials Science, California Institute of Technology, Pasadena, CA, Nature Vol.410 pp.910 -913.

Jyothi1, U. S.; K. V. K. Reddy (2014). "The impact on Combustion, Performance and Emissions of CI Diesel Engine using Hydrogen as Dual Fuel Operation-A Review.” International Journal of Emerging Technology and Advanced Engineering, Volume 4, Issue 12.

Kaveh, M.; b. N. Sulaiman1 and H. Moayed (2012). " Electrical Efficiency of Electrolytic Hydrogen Production." Int. J. Electro hem. Sci., 7. Pp. 3314-3326.

Mario, N. B.; E. N. Bodunov; L. Pogliani (2007).“The van der waals equation: analytical and approximate solutions." journal of mathematical chemistry, vol. 43, No.4.

Ogden, J. M.; L. Fulton and D. Sperling (2014). "Transition Costs in Perspective." manuscript in preparation. 
Romdhane, B. S.; (2013). "Production of Hydrogen by Electrolysis of Water: Effects of the Electrolyte Type on the Electrolysis Performances." Computational Water, Energy, and Environmental Engineering, vol. 23, No 2, pp. 54-58.

Trygve, R.; F. Elisabet, H. Preben, J. S. Vie and y. Ulleberg (2006). "Hydrogen production priorities and gaps." International Energy Agency (IEA), Head of Publications Service, 9 rue de la Federation, 75739 Paris Codex 15, France.

Walt, P.; H. Jim and C. Reynaldo (1994) "Solar Hydrogen Production by Electrolysis" Home Power February / March Pp34:38.

\section{الملغص العربي \\ تصنيع وتقييم وحدة لإنتاج غاز الهيدروجين من المياه}

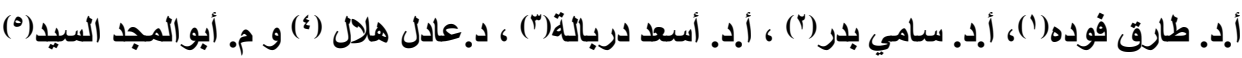
تم إجراء التجربة بوحدة بحوث الهندسة الزراعية ـ المحطة البحثية بالجميزة ـ مركز البحوث

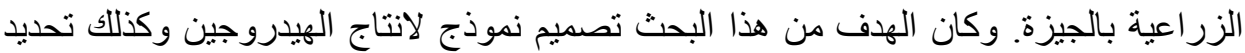

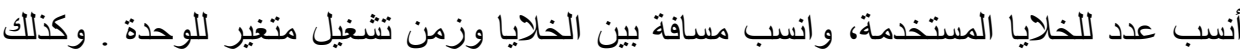

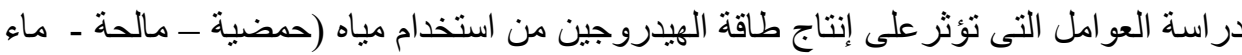

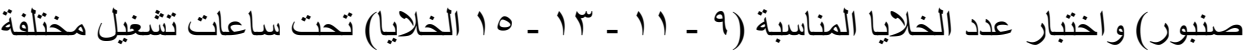

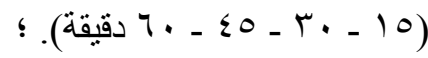

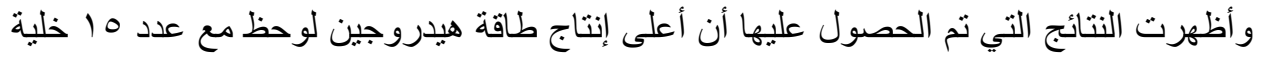

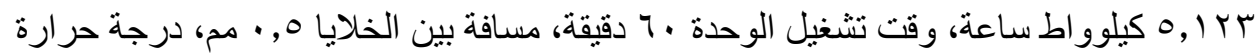

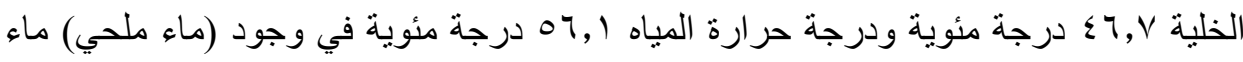

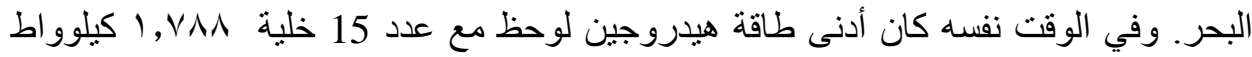

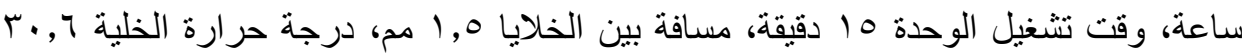

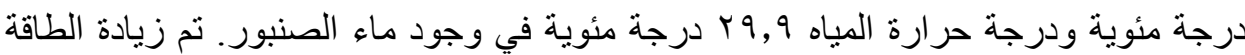

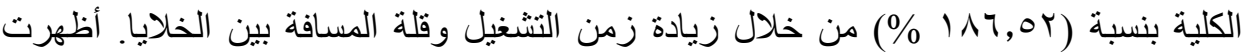

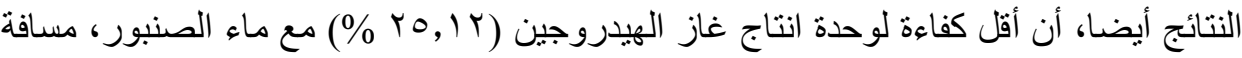

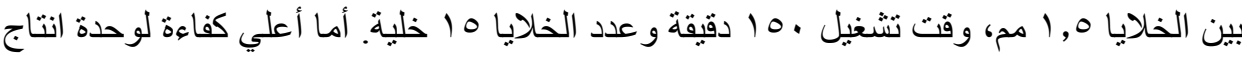

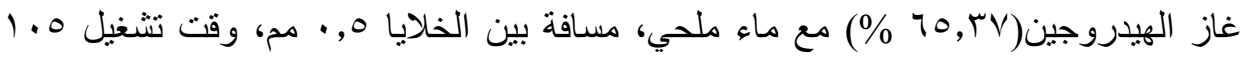
دقيقة و عدد الخلايا 10 الية.

(1) ، (Y) (1) : أستاذ الهندة الزراعية، كلية الزراعة جامعة طنطا.

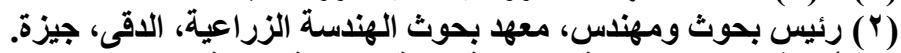

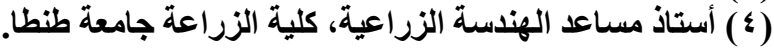
(0) مهندس، معهد بحوث الهندسة الزراعية، الدقى، جيزة. 